\title{
Student and Lecturer Attributes and University Setting in Nurturing Oral Proficiency
}

\author{
Gopala Krishnan Sekharan Nair ${ }^{1}$, Roszainora Setia ${ }^{1}$, Nor Zaitolakma Abdul Samad ${ }^{1}$, Nazrul Nadziruddin Bin

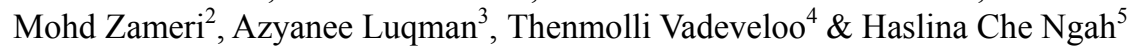 \\ ${ }^{1}$ Academy of Language Studies, Universiti Teknologi MARA (UiTM) Dungun, Terengganu, Malaysia \\ ${ }^{2}$ Lot $5308 \mathrm{Kg}$. Hj. Daud, Atas Tol, 21070 Kuala Terengganu, Terengganu, Malaysia \\ ${ }^{3}$ Faculty of Business Management, Universiti Teknologi MARA, Dungun, Terengganu, Malaysia \\ ${ }^{4}$ Faculty of Administrative Science \& Policy Studies, Universiti Teknologi MARA, Dungun, Terengganu, \\ Malaysia \\ ${ }^{5}$ Faculty of Hotel \& Tourism Management, Universiti Teknologi MARA (UiTM) Dungun, Terengganu, Malaysia \\ Correspondence: Gopala Krishnan Sekharan Nair, Academy of Language Studies, Universiti Teknologi MARA \\ (UiTM) Dungun Campus, 23000 Dungun, Terengganu, Malaysia. E-mail: gopala@tganu.uitm.edu.my
}

Received: July 24, 2013 Accepted: December 9, 2013 Online Published: January 27, 2014

doi:10.5539/ass.v10n3p129 URL: http://dx.doi.org/10.5539/ass.v10n3p129

\begin{abstract}
This study is a survey investigating the factors that influence students to talk in English in English classes. The study found that students do have positive attributes towards talking in English in class. Besides, it was also found, using descriptive statistics, that students perceive that the lecturer attributes and the university settings are conducive towards students' inclination to talk English in English language classes. The student's motivation level was also found to be satisfactory. Inferential statistics using Pearson ' $r$ ' was used to establish the relationship between student attributes and their motivation level towards talking in English in English classes. It was also found that there existed significant relationships between lecturer attributes and students' motivational level towards using English in class. Significant relationships are also established between lecturer attributes and students' motivational level and also university setting and students' motivational level when it comes to students preponderance towards using English in the class. In addition to the above factors, factors such as the students' socio-economic level and the motivation provided by their elementary school teachers should also be investigated. Future researchers should try to find out if those students who received powerful motivation from elementary school teachers end up talking more English in class later on.
\end{abstract}

Keywords: student attributes, lecturer attributes, university setting, oral proficiency, university

\section{Introduction}

This paper seeks to find out whether the students have positive attributes pertaining to talking in English in English language classes. It also attempts to determine whether the lecturer attributes are satisfactory pertaining to students talking in English in English language classes. Additionally, the paper also discusses to establish whether the university setting is satisfactory pertaining to students talking in English in English language classes.

This researcher sought to investigate the English language situation of weak rural students who mainly comprise the pre-diploma program in UiTM. Factors such as student attributes, lecturer attributes and university setting were investigated to find out how they figure in enhancing the students' oral proficiency.

It is possible that Malays from rural areas may view English as an alien language and show little interest in learning it. These Malays would then only use Malay in their daily lives without doing any practice to improve their level of proficiency. This is one of the reasons why this researcher decided to investigate how factors such as student attributes, lecturer attributes and university setting affect the students' capacity for talking English in and outside class, Faradilla (2010).

Malaysian graduates, especially the Malays, are still unable to use the language effectively although they have been exposed to it for at least 11 years. This is evident in the Malays whose English speech is often relatively poorer than their Malaysian Chinese and Indian counterparts despite the status of English in Malaysia (Baharum 
\& Tretiakov, 2007). Since majority of Malays come from a non-English speaking background, they find it difficult to use English for various reasons. They would hardly use English outside of their English classes and would resort to using Malay. They would also use Malay in English classes in some cases. Hence it is pertinent to find out whether the students have proper attributes towards using English. It is also useful to know whether the lecturer attributes and university setting is satisfactory and capable of encouraging students to use English.

\section{Problem Statement of the Study}

English-proficient employees are easier to train as the workplace may use English extensively, Economist (2007). Thus, English may be important in attracting foreign direct investments (FDIs) to the country. According to Khairi Izwan Abdullah et al. (2010), students who have good command of English have more opportunities in landing a job in multinational companies after they graduate. The lack of a good command of English is one of the major factors that prevent students from getting employed in the job sector, Syed Nazri (2007).

In order to prepare the students for the working world, Universiti Teknologi MARA (UiTM) has adopted the English language as its medium of instruction. This approach is done in order to enhance the students' communication skills, Faradilla (2010). However optimal benefits may not realised if students attributes, lecturer attributes and university setting are not suitable for invoking the speaking of English. Norudin and Sofian (2005) stated that there are still signs that the students are reluctant to use the English language to communicate with each other.

Despite the instructors' applying the language in the classroom, students are still reluctant to communicate verbally in English. This may be caused by several factors that affect the students' ability and motivation to converse in English. This is why this researcher thought that it would be pertinent to find out how factors such as student attributes, lecturer attributes and university setting figure on students tendency to converse in English in and out of the classroom.

\section{Method and Material}

The main objective of this study is to study whether student attributes, lecturer attributes and university setting of students is satisfactory pertaining to learners of low English proficiency talking English in English classes.

A self-developed questionnaire was used for data collection. The questionnaire is designed to elicit information pertaining to student attributes and also student perception of lecturer attributes. A pilot study was conducted to test the reliability of the questionnaire before it was used for the study.

\subsection{Target Population}

The population of this study comprises all the pre-diploma students of UiTM Terengganu. According to Malhotra (2004), every research requires a target population that satisfies the characteristics outlined by the researcher. The target population for this study is all pre-diploma students who enrol for the PD002 Pre-Commerce programme in Universiti Teknologi MARA Terengganu (Dungun). The population strength is 150 students. Out of this population, the researcher randomly selected 60 students.

\subsection{Sample}

Most of the PD002 Pre-Commerce students participated in this study, amounting to 60 respondents. The questionnaires were distributed to this sample of respondents through their respective lecturers.

\subsection{Instrumentation}

The research was carried out using a survey methodology which entails the use of a questionnaire. According to Sekaran (2003), a questionnaire is a pre-formulated set of questions that need to be answered by the respondents. Since the questionnaire is self-developed, a pilot study that consisted of a sample 30 students was conducted in order to test its reliability.

These respondents of the pilot study were not involved in the main study. The data collected would be computed and the Cronbach alpha will be determined. The Cronbach alpha denotes the reliability coefficient. The value of the coefficient should be 0.6 or above. The questionnaire was tested for reliability on August 26, 2012. The reliability of the instrument taken as a whole also shows a strong reliability level with a Cronbach alpha of 0.73 . Thus, the researcher had no hesitation in adopting the instrument for use in the study.

\subsection{The Questionnaire}

The questionnaire was divided into five (5) sections, namely section A, B, C, D and E. However only three section are reported in this paper. The researcher used both nominal and ordinal scale for this study. The nominal scale is used in Section A which mainly deals with descriptive data. 


\section{Section A: Demographic Profile}

This section obtains information pertaining to the respondents' demographic data. Information was obtained regarding their age, gender, programme and semester. These data were merely obtained for information sake and may be used later on when the research is further developed. The information is however not actually used in this current study.

\section{Section B: Student attributes}

This section is used to achieve the first objective which was to find out whether or not the students have positive attributes pertaining to talking in English in their English classes.

Section C: Lecturer attributes

Section C contains 12 items and is used in getting data on the respondents' perception on the lecturer's attributes in instilling in them a desire to talk in English. It also elicits information on what the students think of the lecturer's efforts of encouraging them to talk in English and encouraging them to speak English more often.

Section D: University setting or environment

Section D contains 8 items and seeks data on the respondents' perception on the university setting pertaining to their motivation to speak in English in their language classes. The information would assist the researcher to decide whether the students feel that the setting is conducive or otherwise to the talking of English.

\subsection{Data Analysis Technique}

The data obtained from the questionnaire was then transferred into a computer and was processed using SPSS.

\subsection{Frequency Distribution}

Descriptive data was used in examining the respondent's profile. By using the frequency distribution, the researcher was able to categorise various characteristics of the respondents.

\subsection{Inferential Statistics Analysis}

For section $\mathrm{B}, \mathrm{C}$ and $\mathrm{D}$ inferential statistics such as mean, mode and median were used to make a decision pertaining to issues such as students' attributes, lecturer attributes and university setting.

\section{Analysis and Results}

4.1 Respondent's Profile

Table 1. Demographic profile of respondents

\begin{tabular}{llll}
\hline Respondent's Profile & & Frequency & Percentage (\%) \\
\hline Gender & Male & 17 & 28.33 \\
& Female & 43 & 71.67 \\
Age (Years) & Total & 60 & 100.00 \\
& 18 & 55 & 91.70 \\
& 19 & 1 & 1.7 \\
& 20 & 2 & 3.3 \\
Education Level & 23 & 1 & 1.7 \\
& 999 & 1 & 1.7 \\
Programme & Total & 60 & 100.00 \\
& SPM & 60 & 100.00 \\
& Total & 60 & 100.00 \\
& PD002 & 60 & 100.00 \\
& Total & 60 & 100.00 \\
\hline
\end{tabular}




\subsection{Student Attributes in Talking English}

Table 2. Scores for student attributes pertaining to talking in English in English language classes

\begin{tabular}{|c|c|c|c|c|c|}
\hline No. & Items & Mean & Median & Mode & $\begin{array}{l}\text { Standard } \\
\text { Deviation }\end{array}$ \\
\hline 1 & I have good command of English & 2.88 & 3.00 & 3 & .640 \\
\hline 2 & I have sufficient English vocabulary & 2.95 & 3.00 & 3 & .699 \\
\hline 3 & I prefer to use basic English & 3.22 & 3.00 & 3 & .804 \\
\hline 4 & I am confident to talk in English with my friends. & 3.03 & 3.00 & 3 & .758 \\
\hline 5 & I am confident to talk in English with my lecturers. & 2.67 & 3.00 & 2 & .816 \\
\hline 6 & $\begin{array}{l}\text { I am confident to talk in English with the university's } \\
\text { staffs }\end{array}$ & 2.50 & 2.00 & 2 & .834 \\
\hline 7 & $\begin{array}{l}\text { I am comfortable to talk in English on issues that I am } \\
\text { familiar with. }\end{array}$ & 2.82 & 3.00 & 3 & .813 \\
\hline 8 & I use correct grammar when talking in English. & 2.60 & 3.00 & 3 & 8.27 \\
\hline 9 & $\begin{array}{l}\text { I am confident to speak in English in front of my friends } \\
\text { during class. }\end{array}$ & 2.98 & 3.00 & 3 & .875 \\
\hline 10 & $\begin{array}{l}\text { I prefer the lecturers to correct my mistakes during } \\
\text { speaking activities. }\end{array}$ & 3.60 & 4.00 & 3 & 1.028 \\
\hline 11 & I will refer to the dictionary to help me talk in English. & 3.77 & 4.00 & 4 & 1.015 \\
\hline 12 & $\begin{array}{l}\text { I use language strategies (language transfer, } \\
\text { code-switching, pauses, etc.) to talk in English. }\end{array}$ & 2.93 & 3.00 & 3 & .936 \\
\hline 13 & $\begin{array}{l}\text { I will talk in English if there is an extrinsic reward } \\
\text { (grades, extra marks, money, etc.). }\end{array}$ & 2.98 & 3.00 & 3 & 1.000 \\
\hline 14 & $\begin{array}{l}\text { I will talk in English for intrinsic rewards (compliments, } \\
\text { acknowledgements, etc) }\end{array}$ & 2.97 & 3.00 & 3 & 8.23 \\
\hline 15 & $\begin{array}{l}\text { I am more motivated to talk in English in pair or group } \\
\text { activities during class. }\end{array}$ & 3.12 & 3.00 & 3 & .940 \\
\hline
\end{tabular}

The table above shows the mean of the individual items pertaining to students attributes towards conversing in English in the classroom. As can be seen the mean for the individual item is either slightly above 3 or almost 3 , which is the mid-point. This leads the researcher to conclude while there is a certain level of students attributes towards talking English, there is also plenty of room for improvement. 


\subsection{Lecturer Attributes in Talking English}

Table 3. Scores for lecturer attributes pertaining to students talking in English in English language classes

\begin{tabular}{|c|c|c|c|c|c|}
\hline No. & Item & Mean & Median & Mode & SD \\
\hline 1 & The lecturers have good command of English. & 4.52 & 5.00 & 5 & .676 \\
\hline 2 & The lecturers encourage me to talk in English. & 4.25 & 4.00 & 4 & .704 \\
\hline 3 & The lecturers always correct my mistakes during speaking activities. & 4.03 & 4.00 & 4 & .882 \\
\hline 4 & $\begin{array}{l}\text { The lecturers encourage me to use the dictionary to improve my } \\
\text { English in speaking activities. }\end{array}$ & 4.25 & 4.00 & 5 & .816 \\
\hline 5 & $\begin{array}{l}\text { The lecturers motivate me to learn from my mistakes when talking in } \\
\text { English. }\end{array}$ & 4.10 & 4.00 & 4 & .915 \\
\hline 6 & $\begin{array}{l}\text { The lecturers compliment me for my effort to talk in English during } \\
\text { class. }\end{array}$ & 3.92 & 4.00 & 4 & .829 \\
\hline 7 & $\begin{array}{l}\text { The lecturers make efforts for me to keep me talking in English during } \\
\text { class. }\end{array}$ & 3.90 & 4.00 & 4 & .915 \\
\hline 8 & $\begin{array}{l}\text { The lecturers provide me with enough practice and exposure to talk in } \\
\text { English. }\end{array}$ & 4.02 & 4.00 & 4 & .813 \\
\hline 9 & $\begin{array}{l}\text { The lecturers provide me with sufficient opportunities to talk in } \\
\text { English during class. }\end{array}$ & 3.87 & 4.00 & 4 & .853 \\
\hline 10 & $\begin{array}{l}\text { The lecturers pay attention and listen when I talk in English during } \\
\text { class. }\end{array}$ & 3.87 & 4.00 & 4 & 1.016 \\
\hline 11 & $\begin{array}{l}\text { The lecturers' behaviour and personality affect my ability to talk in } \\
\text { English. }\end{array}$ & 3.82 & 4.00 & 4 & 1.017 \\
\hline 12 & $\begin{array}{l}\text { The lecturers use pair and group works to promote me to talk in } \\
\text { English. }\end{array}$ & 4.00 & 4.00 & 4 & .864 \\
\hline
\end{tabular}

The table above shows the mean of the individual items pertaining to students' perception of lecturers' commitment and the encouragement in getting students to converse in English in the classroom. As can be seen the mean for the individual item is either almost 4 or above 4 , whereas the mid-point score would be 3 . This leads the researcher to conclude that on the whole the students find that the lecturers do provide the necessary encouragement and opportunities for students to converse in English. It is heartening to note that the lecturers are doing their part in getting the students to talk more English. There will be further discussion on this on the next chapter. 


\subsection{University Setting in Talking English}

Table 4. Scores for university setting pertaining to talking in English in English language classes

\begin{tabular}{|c|c|c|c|c|c|}
\hline No. & Items & Mean & Median & Mode & SD \\
\hline 1 & The university's setting is conducive for me to talk in English. & 3.77 & 4.00 & 3 & .998 \\
\hline 2 & The university promotes the students to talk in English. & 3.97 & 4.00 & 5 & .991 \\
\hline 3 & $\begin{array}{l}\text { The university is serious in promoting the students to talk in } \\
\text { English. }\end{array}$ & 3.80 & 4.00 & 4 & 1.005 \\
\hline 4 & $\begin{array}{l}\text { The university uses English to convey their messages to the } \\
\text { students. }\end{array}$ & 3.72 & 4.00 & 3 & .922 \\
\hline 5 & $\begin{array}{l}\text { Most of the information posted by the university to its students is in } \\
\text { English. }\end{array}$ & 3.55 & 4.00 & 4 & 1.032 \\
\hline 6 & The university uses English in their activities. & 3.30 & 3.00 & 3 & 1.030 \\
\hline 7 & $\begin{array}{l}\text { The university requires the students to talk in English when dealing } \\
\text { with their staffs. }\end{array}$ & 3.25 & 3.00 & 3 & .985 \\
\hline 8 & $\begin{array}{l}\text { Majority of the forms used to apply various needs from the } \\
\text { university are in English. }\end{array}$ & 3.60 & 4.00 & 4 & 1.045 \\
\hline
\end{tabular}

The table above shows the mean of the individual items pertaining to university setting towards students conversing in English in the English classroom. As can be seen the mean for the individual item are all above 3 but none exceeding 4 . This leads the researcher to conclude that while the university setting is conducive towards enabling students to talk in English, there is also plenty of room for improvement as the sample mean is only slightly higher than the mid-point mean.

\section{Discussion}

The findings revealed that, it wouldn't be entirely accurate to blame the students for our English language woes. The students do have a certain level of keenness and a positive inclination towards wanting to converse in English. Our students do have a desire to attain proficiency in English. Tan (1994) indicated that young Malaysians considered English to be important to the fulfillment of their personal and academic needs. Many students felt that being proficient in English would help them get jobs, and improve their chances for promotion Chew et al. (2006). Hence, it appears that our students do have the desire to be better at English. However, perhaps somehow they fail to achieve reasonable level of English proficiency.

While students do have a positive predisposition towards talking in English, the score while not being unsatisfactory can certainly be improved much further. Teachers should regard their roles as both promoters and salespeople and attempt to instill in students, the desire to talk in English. The mean of 45.02 is only about $60 \%$ of the sample are positively inclined towards talking in English. Ideally, we should get a score which is about $80 \%$.

Teachers and educators should strive to build up student interest in conversing in English. There is ample literature review to support the contention that integrative motivation is a powerful force in driving the students' earnestness in wanting to secure better English proficiency. Learners with positive attitudes towards L2 were more successful in learning the language than those who had negative attitudes, Gardner (1985).

Teachers, educational planners and school heads should be ever mindful that they impress on students the merits of having satisfactory knowledge in English. At the same time, they also have to look to other causes for the lack of proficiency of our students. Students and even their parents are not unaware of the importance of English nonetheless it is widely acknowledged that many of our school leavers do not have proper proficiency in English. (Khairi Izwan Abdullah et al., 2010). The ministry as well as other concerned parties should investigate other reasons for students' lack of proficiency.

This study suggests that investigation should be done on proficiency level of the English teachers themselves as we do not want a situation where the blind would lead the blind. In addition, the curriculum should be reassessed to discern whether it is uninteresting to the students. The suitability of the text used in literature texts also merits 
an evaluation.

It is therefore not farfetched to say that the students themselves are not the sole cause of their dismal state of English proficiency. They appear to have a reasonable level of keenness and readiness as evidenced by the findings. Even the pedagogy used merits being looked into. One cannot conveniently blame the students for all the English proficiency maladies.

The lecturer attributes too can be considered as satisfactory for this purposes of this study. There appears to be nothing seriously in want when it comes to lecturer attributes. Even the student attributes as explained earlier, are not dismal although the score can certainly be much improved. Notwithstanding the encouraging score obtained for lecturer attributes, this researcher feels that there's a lot more that lecturers can do and should do. In the classrooms, lecturers may reward good students with good marks or praising words or punish other students with low marks. Therefore, the reward system itself can be frustrating and demotivating for the

weaker students (Qashoa, 2006). While we must often catch students doing something right, we should not be over eager in catching them doing things wrong (Sharma, 2008). Following Sharma's reasoning, teachers should correct mistakes but not say or do anything which might create anxiety in the student in speaking up and making mistakes. Tanveer (2007) found that often the lecturer's rigid and humiliating method of correcting students' mistakes will cause the students to view class as a performance indicator instead of a friendly learning environment.

The lecturer attributes are indeed important in creating an encouraging classroom atmosphere for talking in English. The lecturer's involvement in the academic setting may also be a barrier to students' attempts to communicate in English. According to Qashoa (2006), lecturers can de-motivate students in learning English. He indicates that both the instructor's styles and personality traits can produce negative effects on students who are learning the English language. Thus, the lecturers must ever be mindful of these. These de-motivating factors include the teacher's nervousness, loss of class control and the use of scolding words. Reprimands can be given but with compassion such that it encourages the students to better themselves.

Meanwhile, it is legitimate to conclude that the university setting has some level of conduciveness pertaining to students' desire to converse in English although the level is not very high.Thus, the university needs to adopt a more encouraging environment for the students to talk in English. A university that promotes the use of English can encourage the students to talk in English regardless of their level of English proficiency. An environment that is not conducive for the use of English on the other hand, makes it difficult for the students to practise using the language.

The university also needs to provide situations or environments where students can engage the language in real-life situations. Languages learners should be able to use the language more successfully when they are involved in real-life situations (Karimnia et al., 2007). Moreover, the main goal of language classes is to ensure that language learners can use the language in real-life situations effectively and this can be done by creating an environment that encourages students to use the language.

The university should also be wary of the factors that can discourage the students from using the language in their university environment. Factors such as the learning method and the learning environment can cause the learning of a foreign language to be inconvenient (Karimnia et al., 2007). It should be noted that motivation and proficiency are not sufficient for students to use the language when they are outside the language classrooms if the environment is not supportive of their desire to speak in English.

Matsuoka (2005) believes that motivation and language proficiency alone are not adequate in encouraging the students to either start or participate in conversations that use languages that they are less familiar with when they are exposed to real-life context outside of their language classrooms. Thus, an environment that allows students to use the language is important. Matsuoka suggests that an environment that promotes the use of English can encourage students with low English proficiency to talk in English even when their proficiency levels are far from satisfactory. Matsuoka believes that such attempts to improve language proficiency and comprise of important integral in language the learning processes. An unsupportive environment will deter even those who are proficient in English to use English outside the classroom.

\section{Conclusions and Recommendations}

The findings of this study would probably highlight to teachers and administrators that university setting and students' motivation level has an important bearing in our attempts to get students to be more proficient in English. It is humbly suggested that instructors and university administrators make every effort to create an environment and climate which is conducive to the use of English. 
The findings showed that the students are favourably inclined to talking in English. There are no defects in the student in this respect. They do have the interest, the onus is on instructors and administrators to nurture this interest rather than allow a budding interest to wither away without proper encouragement.

It was also found that the instructors do have favourable attributes pertaining to students' inclination to talk English in class. However, the current unsatisfactory situation shows that there is plenty of room for improvement. Instructors and the administrations should be more energetic and robust in encouraging students' inherent interest to talk English in the campus.

Lecturers and educational planners should never underrate the importance of the university setting and environment in getting students to talk in English. The student should at all times be made to feel that he is not alone in his noble and worthy quest to become more proficient in English. The setting and environment should be such that a student is induced to use English.

It is good to know that students do have positive perception towards English which indicates that they have the motivation to use the language. Thus, it would be unfair to label students as having no motivation in learning the language. Moreover, language instructors should play their part by encouraging students to talk in English in their language classes. In addition, the university should make efforts to create an environment which motivates their students to practise the language.

The study rebutted the belief that the students' inability to use English effectively is mainly caused by their negative outlook on the language. The result of the study shows that students do possess a positive view of the language as they realise the importance of the language in both their studies and in their future. Thus, it would be unwise and inconvenient to put the blame solely on language learners when there are other variables that affect their ability to use English in real-life situations.

Hence, it is important for future language instructors to dismiss the notion that the students view English negatively and such view is the sole cause of students' lack of proficiency which could affect their ability to use the English later.

Another implication is that language instructors do play a vital role in motivating the students to use the language. Language instructors should produce lessons that motivate their students to learn and use the language. Moreover, language teachers should avoid actions that can make the students feel discouraged in using the language. Instead of blaming the students of their lack of English proficiency, instructors should focus on remedial actions that can improve the chances of students talking in English. Thus, it is vital that instructors should plan lessons that are geared towards the needs of their students instead of putting the blame of their students when the students lack the necessary language skills.

Besides, the study also implies that language skills can be improved when students are in a setting that encourages the use of the target language. It should be noted that the students themselves realise the importance of using the language effectively in real-life situations. A setting that promotes the use of English is important as it allows the students to practise their language skills in real-life settings. It should be noted that even students who are proficient in English find it to be challenging to use the language effectively when they are less familiar with the context, let alone low proficient English learners. Thus, the university should provide opportunities for students to practise the language. In addition, it should be noted that it is vital to expose learners to proper context of English language use. There should be attempts to carry out student activities and meetings in English and where possible there should be notices in English. A conducive setting would provide real-life contexts for students to use English. This would be effective compared to only teaching the language as a rigid component of the syllabus.

\section{References}

Abdullah, K. I., \& Rahman, N. L. A. (2010). A Study on Second Language Speaking Anxiety among UTM $\begin{array}{lllll}\text { Students. } & \text { Retrieved } & \text { December } & \text { 2012, from }\end{array}$ http://eprints.utm.my/10275/2/Nurul_Lina_Bt_Abdul_Rahman.pdf

Baharum, H. I., \& Tretiakov, A. (2007). Teaching business English to adult Malay learners: The potential of agent technology. Retrieved December 1, 2012, from http://www.ascilite.org.au/conferences/singapore07/procs/baharum.pdf

Chew, P. C., Francis, A., \& Evanson, V. J. (2006). A Need Analysis of the English Language Requirements in the Field of Science and Technology: Universiti Teknologi MARA Students' Perception. Unpublished Academic Study, Universiti Teknologi MARA. 
Economist Correspondent. (2007). Asian Economies. The Economists, March 5.

Faradilla, E. (2010). Attitude towards Use of ICT and its Actual Level of Use in English Language Teaching in Miri, Sarawak. Unpublished Academic Study, Universiti Teknologi MARA

Gardner, R. C. (1985). Social Psychology and Second Language Learning: The Role of Attitude and Motivation. London: Edward Arnold.

Karimnia, A., \& Zade, S. S. (2007). Communication strategies: English language departments in Iran. Iranian Journal of Language Studies (IJLS), 1(4), 287-300.

Malhotra, N. K. (2004). Marketing Research (4th ed.). Pearson Education, Inc., New Jersey, USA.

Mansor, N., \& Ahmad, S. (2005). A Critical Evaluation of English Communication Usage among University Students, Proceedings "Towards Academic and Service Excellence Through Professionalism", Universiti Teknologi MARA (UiTM), Terengganu, Malaysia.

Matsuoka, R. (2005). Willingness to Communication among Japanese college students. Retrieved December 11, 2012, from http://www.paaljapan.org/resources/proceedings/PAAL10/pdfs/matsuoka.pdf

Qashoa, S. (2006). Motivation among learners of English in the secondary schools in the eastern coast of the UAE. M. A. thesis, British University in Dubai.

Sekaran, U. (2003). Research Methods for Business - A Skill Building Approach (4th ed.). John Wiley \& Sons, Inc., USA.

Sharma, R. (2008). The Greatness Guide. Harper, New York.

Syed, N. (2007). The Case for Better English. New Strait Times, August 5.

Tan, R. (1994). Readings in English as an International Language. London: Pergamon Press. Arts and Social Sciences in the Universiti of Malaya. Unpublished M.A. thesis. Universiti Malaya, Malaysia.

Tanveer, M. (2007). Investigation of the factors that cause language anxiety. Asian EFl Journal. Retrieved from http://asian-efl-journal.com/thesis_M_Tanveer.pdf

\section{Copyrights}

Copyright for this article is retained by the author(s), with first publication rights granted to the journal.

This is an open-access article distributed under the terms and conditions of the Creative Commons Attribution license (http://creativecommons.org/licenses/by/3.0/). 